\title{
INTERAKSI SIMBOLIK RITUAL TRADISI MITONI BERDASARKAN KONSEP IKONOLOGI-IKONOGRAFI ERWIN PANOFSKY DAN TAHAP KEBUDAYAAN VAN PEURSEN DI DAERAH KROYA, CILACAP, JAWA TENGAH
}

\author{
Nama: Probosiwi, S.Sn., M.Sn. \\ Institusi: Program Studi Sekolah Dasar Universitas Ahmad Dahlan Yogyakarta \\ e-mail: probosiwi@pgsd.uad.ac.id
}

\begin{abstract}
ABSTRAK
Penelitian ini menganalisis visualisasi simbolik pada ritual tradisi mitoni di era masa kini berdasarkan aspek Ikonologi-Ikonolografi Ewin Panofsky. Selain itu, penulis untuk mengetahui perubahan dan interaksi simbolik di dalamnya melalui tahap kebudayaan Van Peursen. Jenis penelitian yang akan digunakan yaitu kualitatif. Sampel penelitian adalah kegiatan ritual tradisi mitoni yang dilakukan di daerah Kroya, Cilacap, Jawa Tengah. Pengumpulan data dilakukan dengan cara observasi, wawancara, dan studi referensi. Teknik analisis data dilakukan dengan teknik menganalisis secara rinci data-data yang terkumpul melalui hasil kajian pustaka, wawancara dan observasi langsung juga tidak langsung terhadap subjek pelaku ritual serta uborampe yang digunakan. Hasil penelitan menunjukkan bahwa terjadi perubahan dan pengembangan ritual tradisi mitoni pada era masa kini berdasarkan tahapan-tahapan kebudayaan yang telah dituliskan oleh Prof. Dr. C. Van Peursen. Tahapan-tahapan kebudayaan yang telah dilalui dapat dianalisis visualnya yaitu seperangkat alat dan bahan yang digunakan dalam ritual melalui ikonologi dan ikonografi Erwin Panofsky.
\end{abstract}

Kata Kunci: Mitoni, Ikonologi-Ikonografi, Tahap-tahap Kebudayaan

\begin{abstract}
The purpose of this research is to analyze the symbolic visualization of the ritual of mitoni tradition in the present era based on Iconology-Iconology aspect of Ewin Panofsky. In addition, the author to know the changes and symbolic interactions in it through the cultural phase of Van Peursen. The type of research to be used is qualitative. The sample of research is the ritual activity of mitoni tradition which is done in Kroya area, Cilacap, Central Java. Data collection was done by observation, interview, and reference study. Data analysis technique is done by analyzing technique in detail data collected through result of literature study, interview and direct observation also indirectly to subject perpetrator of ritual and uborampe used. The research results show that there is a change and the development of the ritual of mitoni tradition in the present era based on the cultural stages that have been written by Prof. Dr. C. Van Peursen. Stages of cultures that have been passed can be analyzed visually is a set of tools and materials used in rituals through iconology and iconography Erwin Panofsky.
\end{abstract}

Keynote: Mitoni, Iconology-Iconography, Culture 


\section{PENDAHULUAN}

\section{A. Latar Belakang Masalah}

Budaya merupakan keseluruhan sistem gagasan, tindakan, dan hasil karya manusia dalam rangka kehidupan masyarakat yang dijadikan milik diri manusia dengan belajar. Menurut Koentjaraningrat (1987:15), pengertian kebudayaan adalah keseluruhan sistem gagasan, tindakan, dan hasil karya manusia dalam rangka kehidupan masyarakat yang dijadikan milik diri manusia dengan belajar. Masyarakat sendiri terdiri dari manusia yang memiliki berbagai macam latar belakang pendidikan, agama, ras, dan suku yang terbalut dalam kehidupan sosial.

Keseluruhan sistem yang dimaksud tersebut diatur di dalam tatanan suatu kehidupan sosial dan diikuti oleh masing-masing indvidu yang berdomisili di daerah tertentu. Sistem yang dimaksud adalah aturan-aturan yang tidak tertulis, bisa berupa tradisi lisan dari leluhur secara turun-temurun. Masyarakat pun meyakini bahwa nenek moyang mereka melakukan tradisi serupa seperti yang dilakukan saat ini. Tujuannya pun bermacam-macam ada yang difungsikan untuk memohon keberkahan, kelancaran, mencari hari baik, keselamatan, dan sebagainya.

Bentuk dari kebudayaan masyarakat Jawa adalah cerita atau mitos yang muncul, seperti anak gadis dilarang keras makan di depan pintu, karena bisa batal dilamar orang alias balik kucing. Mitos lain, calon pengantin perempuan dilarang keras keramas mendekati hari-H pernikahan supaya tidak turun hujan deras ketika resepsi berlangsung yang bisa mengacaukan acara. Ada pula mitos lain, jika ada orang yang sedang menyapu harus dikerjakan hingga tuntas agar rejeki tidak tersendat. Beberapa mitos tersebut masih berkembang pesat hingga saat ini dan diyakini akan terjadi malapetaka, kerugian, atau bencana apabila masyarakat melanggarnya. Mitoni adalah salah satu bentuk mitos warga masyarakat Jawa, khususnya di kawasan Kroya, Cilacap, Jawa Tengah.

Mitos semacam cerita prosa rakyat yang benar-benar terjadi, dianggap suci oleh empunya cerita, dan ditokohi oleh para dewa atau mahkluk setengah dewa. Peristiwa yang diangkat seolah terjadi di dunia lain atau di dunia yang bukan dikenal oleh manusia sekarang serta terjadi masa lampau. Mitos merupakan salah satu dari tradisi lisan yaitu dalam bentuk cerita lisan yang dapat dikategorikan dalam ragam sastra lisan. Sastra lisan adalah karya sastra yang diwariskan turun- 
temurun secara lisan, salah satunya adalah cerita rakyat (folklore). Folklore digolongkan ke dalam tiga kelompok besar berdasarkan tipenya sebagai berikut folklor lisan (verbal folklore), folklor sebagian lisan (partly verbal folklore), dan folklor bukan lisan (non verbal folklore). (James Danandjaja, 1984: 21) Mitos menurut sistem kepercayaan dari suatu kelompok manusia, yang berdiri atas sebuah landasan yang menjelaskan cerita-cerita yang suci yang berhubungan dengan masa lalu. Mitos yang dalam arti asli sebagai kiasan dari zaman purba merupakan cerita yang asal usulnya sudah dilupakan, namun ternyata pada zaman sekarang mitos dianggap sebagai suatu cerita yang dianggap benar. Manusia memerlukan sekali kehadiran alam sehingga terjadi hubungan yang erat antara manusia dan alam. (Harsojo, 1998)

Mitoni berasal dari kata "pitu" yang artinya tujuh, dimaksudkan bahwa mitoni/ tingkeban adalah ritual yang dilaksanakan pada saat bayi memasuki usia kandungan tujuh bulan. Mitoni juga disebut sebagai tradisi tingkeban yang diperuntukan bagi perempuan yang telah menikah dan sedang mengandung calon anak di usia tujuh bulan. Serangkaian persiapan pun dilakukan untuk menjalankan ritual ini seperti siraman, pecah kelapa, brojolan, membuat jenang, berganti kain jarik dengan berbagai motif, dan kelapa gading yang diberi gambar tokoh-tokoh wayang. Gambar tokoh wayang menjadi simbol agar anak yang dilahirkan nanti memiliki watak atau karakter seperti yang digambarkan, sehingga gambar tersebut merupakan simbol yang wajib ada di dalam upara mitoni. Figur tokoh wayang yang biasa digunakan adalah Arjuna-Sembadra atau Kamajaya-Kamaratih. Sesuai dengan karakteristik masyarakat Jawa yang sangat kental dengan penggunaan simbol-simbol sebagai wujud representasi terhadap sesuatu hal. Bagi golongan bangsawan, sajen (sesaji) yang biasa dibuat adalah tumpeng robyong, tumpeng gundul, sekul asrep-asrepan, ayam hidup, sebutir kelapa, lima macam bubur, dan jajan pasar. Untuk kegiatan kenduren (kenduri) berupa nasi majemukan, tujuh pasang nasi, pecel ayam, sayur menir, ketan kolak, apem, nasi gurih, ingkung, nasi punar, ketupat, rujak dan dawet, emping ketan, air bunga, serta kelapa tabonan. Sedangkan bagi golongan rakyat biasa, sajen (sesaji) cukup dengan sego jangan, jajan pasar, jenang abang putih, jenang baro-baro, emping ketan, tumpeng robyong, sego golong, sego liwet, dan bunga telon. Untuk hidangan kenduren (kenduri) dibuatkan sego gurih, sego ambengan, jajan pasar, ketan 
kolak, apem, pisang raja, sego jajanan, tujuh buah tumpeng, jenang, kembang boreh, dan kemenyan.

Mitoni dilakukan dengan menghitung terlebih dahulu hari dan tanggal tepat menurut tanggalan (kalender) Jawa. Kalender adalah penanggalan yang memuat nama-nama bulan, hari, tanggal, dan hari-hari keagamaan seperti terdapat pada kalender Masehi. Kalender Jawa memiliki arti dan fungsi tidak hanya sebagai penunjuk hari tanggal dan hari libur atau hari keagamaan, tetapi menjadi dasar serta ada hubungannya dengan apa yang disebut petangan Jawi, yaitu perhitungan baik-buruk yang dilukiskan dalam lambang dan watak dari suatu hari, tanggal, bulan, tahun, pranata mangsa, wuku, dan lain-lain. (Purwadi, 2010:14) Ritual tradisi mitoni memberikan harapan baru bagi kehidupan calon bayi yang ada di dalam kandungan, sehingga proses kehamilan mendapat perhatian tersendiri bagi masyarakat setempat. Harapan-harapan muncul terhadap bayi dalam kandungan, agar mampu menjadi generasi yang handal di yang akan datang. Oleh karena itu, sebagian masyarakat Jawa masih melaksanakannya yang dirasa mampu mewujudkan keinginan mereka terhadap calon anak tersebut.

Representasi menjadi kekuatan simbolik pada upacara mitoni dalam menggambarkan jalannya kehidupan manusia mulai dari cikal-bakal (janin) hingga menuju ke proses kelahiran agar senantiasa diberi kelancaran. Pemilihan figur wayang tertentu, secara konseptual, dibuat berdasarkan kesadaran dan kepekaan para leluhur dalam menangkap fenomena kehidupan manusia yang dapat disimbolkan. Keberadaan simbol di dalam upacara mitoni seringkali menjadi lebih kuat menggambarkan suatu kondisi atau fenomena tertentu. Simbolsimbol dihadirkan untuk melengkapi ritual upacara tersebut yang akan dilakukan seperti berasal dari tanaman, buah-buahan, makanan, pakaian, dan sebagainya. Hal tersebut merupakan representasi kepada tujuan yang dimaksud sebagai contoh untuk kebahagiaan, kemuliaan, keamanan, kesejahteraan dan lain-lain.

Masyarakat Jawa masa kini masih menerapkan tradisi mitoni meskipun terdapat langkah-langkah dan beberapa sesaji yang tidak semua ditampilkan. Bentuk-bentuk perubahan tersebut diakibatkan oleh pola pikir masyarakat yang lebih rasionla serta membawa kesan religius ke dalam proses ritual. Persepsi pikiran masyarakat terhadap interkasi simbolik di dalam tradisi mitoni dapat dianalisis dan dikorelasikan dengan perkembangan pola pikir masa kini. Terlebih lagi, di kawasan Kroya, Cilacap, Jawa Tengah masih sangat memegang teguh 
tradisi di tengah pesatnya perkembangan zaman. Di satu sisi mengembangkan pendidikan bagi generasi penerus dan di sisi lain masih mempertahankan tradisi folklornya. Hal ini, tentu saja dapat menjadi pendidikan spiritual bagi generasi penerus melalui kekuatan simbolik. Penulis melakukan penelitian perilaku masyarakat Jawa berdasarkan tiga tahap kebudayaan menurut Van Peursen dan interaksi simbolik pada ritual mitoni dengan ikonologi-ikonografi Erwin Panofsky.

\section{B. Rumusan Masalah}

1. Bagaimana visualisasi simbol di dalam ritual tradisi mitoni berdasarkan konsep Ikonologi-Ikonografi Erwin Panofsky?

2. Bagaimana interaksi simbolik di dalam ritual tradisi mitoni dengan persepsi pikiran masyarakat Kroya, Cilacap, Jawa Tengah menurut tahap kebudayaan Van Peursen?

\section{Landasan Teori}

\section{Tahap Kebudayaan}

\section{a. Tahap Mitis}

Tahap mitis adalah sikap manusia yang merasakan dirinya terkepung oleh kekuatan-kekuatan gaib di sekitarnya. Kekuatan-kekuatan tersebut merupakan kekuasaan dewa-dewa alam raya atau kekuasaan akan kesuburan seperti yang dipentaskan oleh masyarakat primitif. (Hartoko, 1988: 18) Alam pikiran mitis identik dengan kebudayaan primitif yang mengandung suatu filsafat yang dalam, gambaran-gambaran ajaib, dan adat-istiadat yang beraneka ragam. Hal ini berkaitan dengan manusia yang berhubungan dengan daya-daya alam yang serba rahasia serta belum dikacaukan oleh teknologi canggih. (Van Peursen, 1988: 34-35)

Menurut Van Peursen, mitos adalah sebuah cerita yang memberikan pedoman dan arah tertentu kepada sekelompok orang. Cerita itu dituturkan tetapi juga diungkapkan melalui tarian atau pementasan seni pertunjukan seperti wayang. Inti cerita berupa lambang-lambang kebaikan dan kejahatan, kehidupan, kematian, dosa, penyucian, perkawinan, kesuburan, firdaus, serta akherat. (Van Peursen, 1988:36) 
Fungsi mitos meliputi: 1) menyadarkan manusia bahwa ada kekuatankekuatan ajaib; 2) mitos memberi jaminan bagi masa kini; 3) perantara antara manusia dan daya-daya kekuatan alam; 4) memberi pengetahuan tentang dunia (keterangan-keterangan) dalam ranah keilmuan para ahli disebut kosmogoni (cerita terjadinya langit dan bumi) serta theogoni (dongeng-dongeng terjadinya dewa-dewa). (Van Peursen, 1988:40-41)

\section{b. Tahap Ontologis}

Tahap ontologis yaitu sikap manusia yang tidak hidup lagi dalam kepungan-kepungan mitis, melainkan yang secara bebas ingin meneliti segala hal ikhwal dengan mengambil jarak terhadap segala sesuatu yang dirasakan sebelumnya sebagai kepungan. Tahap ini membawa manusia menyusun suatu ajaran mengenai segala yang terjadi di dunia ini menurut perinciannya (ilmu-ilmu). Ontologi berkembang di dalam lingkungan kebudayaan kuno yang sangat dipengaruhi oleh filsafat dan ilmu pengetahuan. (Van Peursen, 1988:18)

Fungsi pemikiran ontologis meliputi 1) membuat suatu peta mengenai segala sesuatu yang mengatasi manusia; 2) menampakan dunia transenden dan dapat dimengerti; 3) seperti halnya tahap mitis, ontologis juga menjamin masa kini namun diterangkan dengan bertitik pangkal pada hukum-hukum abadi; 4) menyajikan pengetahuan dan menonjolkan pengetahuan sistematis yang dapat dikontrol untuk menggali penyebab dari segala sesuatu. (Van Peursen, 1988:59,64,66)

\section{Tahap Fungsionil}

Tahap fungsionil merupakan sikap dan alam pikiran yang makin nampak di dalam manusia modern. Manusia sudah tidak terpesona atau terpukau lagi oleh lingkungannya terhadap hal-hal mitis dan mulai kritis dalam mengambil jarak terhadap objek penyelidikan (ontologis). (Van Peursen, 1988:18)

Fungsi tahapan fungsionil menunjukkan adanya pengaruh terhadap sesuatu yang lain; tidak berdiri sendiri, justru mengandung arti dan makna dalam suatu hubungan; menjadikan manusia modern sadar mengenai kebudayaannya, sehingga terbukalah kemungkinan-kemungkinan baru bagi suatu policy kebudayaan; manusia menyadari terdapat pergeseran dan 
menjadikan fungsionil sebagai pegangan; dan membebaskan manusia dari substansialisme yang pernah mengurung sebelumnya.

\section{Javanisme (Religi Orang Jawa)}

Javanisme atau Javaneseness berasal dari kata kejawen atau keJawaan yang diterjemahkan dalam Bahasa Inggris. Istilah ini merupaka deskripsi atas unsur-unsur kebudayaan Jawa yang dianggap sebagai hakikat Jawa dan yang mendefinisikannya sebagai sutau kategori khas/ kekhasan. Javanisme merupakan pandangan hidup orang Jawa yang menekankan ketenteraman batin, keselerasan dan keseimbangan, sikap nrimo (mau menerima) terhadap segala peristiwa yang terjadi sambil menempatkan individu di bawah masyarakat serta masyarakat di bawah alam semesta. (Pujileksono, 2016:110) Kejawen bisa dimaknai sebagai suatu paham yang mengarah pada kepercayaan, kebatinan, dan tradisi Jawa, sehingga subjek pelaku tidak harus berasal dari masyarakat asli, mereka yang berdomisili di Jawa dapat menganut aliran ini. Suatu aliran kepercayaan yang melekat pada diri manusia dilakukan secara rutin melalui ritual tertentu sebagai wujud pemujaan, rasa syukur, dan permohonan kepada Sang Agung.

Ciri pandangan hidup orang Jawa adalah realitas yang mengarah pada pembentukan kesatuan Numinus antara alam nyata, masyarakat, dan alam kodrati yang dianggap keramat. Alam pikiran orang Jawa merumuskan kehidupan manusia berada dalam dua alam (kosmos), yaitu makrokosmos dan mikrokosmos. (Pujileksono, 2016:110) Di dalam makrokosmos, pusat alam semesta adalah Tuhan di mana alam semesta memiliki hierarki yang ditujukan dengan adanya jenjang alam kehidupan dan tingkatan dunia yang semakin sempurna (dunia atas $3 / 4$ dunia manusia 3/4 dunia bawah). Alam semesta terdiri dari empat arah utama ditambah satu pusat, yaitu Tuhan yang mempersatukan dan memberikan keseimbangan. Sedangkan mikrokosmos tercermin di dalam kehidupan manusia dengan lingkungannya, susunan manusia dalam masyarakat, tata kehidupan manusia sehari-hari, dan segala sesuatu yang nampak oleh mata. Pusat mikrokosmos (pusat dunia) berada pada pimpinan atau raja dan keraton. Alam pikir, sikap, dan pandangan hidup orang Jawa pada zaman kerajaan menempatkan Tuhan sebagai pusat makrokosmos, sedangkan raja dianggap perwujudan 
perwakilan Tuhan di dunia, sehingga di dalam dirinya terdapat keseimbangan berbagai kekuatan dari dua alam.

Budaya kejawen memahami kepercayaan pada berbagai macam roh yang dapat menimbulkan musibah, bahaya, kecelakaan, penyakit apabila mereka dibuat amarah, atau penganutnya tidak berhati-hati. Untuk menangkal hal-hal buruk, orang Jawa kejawen memberi sesajen (sesaji) yang terdiri dari nasi, aneka makanan lainnya, dedaunan, bunga, hingga kemenyan. Mereka juga melakukan kegiatan tirakat (puasa), bertapa, meditasi (semedi). Aktivitas ini biasanya dilakukan di lokasi yang dianggap keramat.

Karakteristik budaya Jawa adalah religius, non-doktriner, toleran, akomodatif, dan optimistik. Karakter-karakter ini melahirkan corak, sifat, serta kecenderungan yang khas bagi masyarakat Jawa seperti: 1) percaya kepada Tuhan Yang Maha Esa sebagai sangkan paraning dumadi dengan segala sifat dan kebesarannya; 2) bercorak idealistis, percaya kepada sesuatu yang bersifat immaterial (bukan kebendaan) dan hal-hal bersifat akodrati (supranatural) serta cenderung ke arah mistik; 3) lebih mengutamakan hakikat daripada segi-segi formal dan ritual; 4) mengutamakan cinta kasih sebagai landasan pokok hubungan antar manusia; 5) percaya kepada takdir dan cenderung bersikap pasrah; 6) bersifat konvergen dan universal; 7) momot dan non-sektarian; 8) simbolisme; 9) gotong royong, 10) guyub, rukun, damai; 11) kurang kompetitif dan mengutamakan materi. (Suyanto dalam Pujileksono, 2016: 112) Mitoni dilingkupi oleh berbagai macam aktivitas dan uborampe yang digunakan serta mengandung beberapa karakter yang telah disebutkan.

\section{Ikonologi-Ikonografi}

Erwin Panofsky menuturkan bahwa

"iconogaphy is that branch of the history of art which concerns itself with the subject matter or meaning of works of art, as opposed to their form. The identification of such images, stories, and allegories is the domain of what is normally referred to as iconography. The discovery and interpretation of these "symbolical" values (which are often unknown to the artist himself and may even emphatically differ from what he consciously intended to express) is the object of what we may call "iconology" as opposed to "iconography". (Panofsky, 1955: 29 \& 31). 
Ikonografi adalah cabang sejarah seni tentang subject matter atau makna karya seni, sebagai perlawanan bentuk-bentuk karya seni yang mencoba untuk memaknai perbedaan antara subject matter atau makna pada satu orang dan orang lain. Pemaknaan dilakukan pada susunan yang membentuk pola secara umum atas warna, garis dan volume yang mengangkat dunia visual. Susunan yang dimaksud adalah sebuah objek ksatria (gentleman) dan detail perubahan sebagai sebuah peristiwa (hatlifting). Panofsky melewati batasan-batasan persepsi formal yang natural dan memasukkan ruang lingkup subject matter atau makna yaitu:

a. Makna merupakan dasar dan sebagai pemahaman alami yang mudah dan kita dapat menyebutnya makna faktual (makna sesungguhnya).

b. Makna memahami dengan cara yang mudah untuk mengidentifikasi bentuk-bentuk visual yang jelas dengan objek-objek yang jelas yang diketahui dari pengalaman praktis.

c. Mengidentifikasi perubahan di dalam hubungan aksi nyata atau melalui peristiwa.

Panofsky melakukan interpretasi dalam mengangkat kehormatan sebagai sebuah sambutan kesopanan, memperkenalkan makna aksi yang mungkin saja dapat dikatakan yang kedua (konvensional); aksi ini berbeda dari sikap utama atau alami dapat dimengerti sebagai pengganti menjadi pantas dan menanamkan secara sadar terhadap aksi praktis yang disampaikan. Selain mengangkat peristiwa alami di dalam ruang dan waktu, mengindikasi selera atau rasa secara alami dan menyampaikan sambutan konvensional, aksi perkenalan dapat mengungkapkan pengalaman pengamat yang semuanya berupaya untuk memoles "personalitas". Dalam hal ini, personalitas adalah kondisi manusia pada abad ke-20 dilatarbelakangi nasional, sosial, dan pendidikan dengan melihat kembali sejarah kehidupan, serta hal-hal yang terjadi di sekitar mereka. Tetapi, personalitas juga membedakan dengan cara individu dalam melihat benda dan member aksi terhadap dunia yang jika dirasionalkan akan dapat dikatakan sebagai sebuah filosofi.

Iconolgy, then, is a method of interpretation which arises from synthetis rather than analysis. And as the correct identification of motifs is the prerequisite of their correct iconographical analysis, so is the correct analysis of images, stories, and 
allegories the prerequisite of their correct iconological interpretation. (Panofsky, 1955: 32) Iconographical analysis, dealing with images, stories, and allegories instead of with motifs, presupposes, of course, much more than that familiarity with objects and events which we acquire by pratical experience. (Panofsky, 1955: 35)

Ikonologi mengacu pada metode menginterpretasi sintesis dan mengidentifikasi objek (image), cerita, dan alegori, sedangkan analisis ikonografi objek merupakan hasil dari pengalaman. Erwin Panofsky membagi tiga tahapan analisis ikonografis yaitu:

\section{1) Deskripsi Pra-Ikonografis: Batasan Dunia Motif (Tema)}

Objek dan peristiwa yang direpresentasi melalui garis, warna dan volume mengangkat dunia motif (tema) untuk bisa diidentifikasi pada dasar pengalaman praktis. Tiap orang dapat mengenali bentuk dan perilaku manusia, hewan, tumbuhan dan dapat menyebut wajah marah dari seorang yang periang. Bidang representasi dihubungkan dengan permasalahan khas yang diatur berdampingan dengan fakta objek, peristiwa dan ekspresi yang digambarkan pada karya seni yang mungkin tidak dapat dikenali karena ketidakmampuan atau perencanaan terlebih dahulu dari senimannya. Pada prinsipnya, tidak mungkin untuk mencapai deskripsi pra-ikonografis yang tepat atau identifikasi permasalahan utama melalui penggunaan pengalaman praktis yang pandang bulu terhadap karya seni. Pengalaman praktis sangat diperlukan sebagai materi atau bahan untuk deskripsi pra-ikonografis, tetapi hal ini tidak dijamin bisa menghasilkan ketepatan. Deskripsi pra-ikonografis dapat dikatakan sebagai what we see, artinya identifikasi motif (tema) pada dasar pengalaman praktis yang murni dan sederhana berdasarkan objek dan peristiwa ditunjukkan melalui bentuk-bentuk di bawah pengaruh kondisi historis, sehingga subjek pada karya berdasarkan pengalaman praktis tehadap prinsip yang dapat diperbaiki dan dapat dikatakan sebagai gaya historis.

\section{2) Analisis Ikonografis}

Tahap analisis ikonografis terletak pada gambar, cerita, dan kiasan daripada motif (tema), tentu saja mensaratkan lebih banyak keakraban dengan objek serta peristiwa dengan pengalaman praktis. Analisis ini merupakan kedekatan pengalaman praktis dengan tema atau konsep spesifik sebagai kelanjutan sumber daya literasi yang dibolehkan dengan pembacaan penuh tujuan atau 
tradisi lisan. Makna ikonografis pada gambar harus memiliki keakraban antara seniman dengan konten pada karya, ketika makna ini hadir sebagai representasi tema selain cerita atau adegan dari sejarah dan mitologi yang rata-rata diketahui oleh "orang-orang yang berpendidikan" di masyarakat.

Seniman atau pengkaji harus mendekatkan diri dengan penulis yang merepresentasikan apa yang telah dibaca atau diketahui oleh orang lain. Tema dan konsep disambungkan dengan sumber literasi dan materi cukup untuk analisis ikonografis, tetapi tidak ada jaminan bahwa hal tersebut benar. Hal ini hanyalah kemungkinan untuk memberikan analisis ikonografis yang benar dengan menyediakan pengetahuan literasi yang tidak pandang bulu terhadap motif (tema). Selain itu, memberikan deskripsi pra-ikonografis dengan benar melalui pengalaman praktis yang tidak pandang bulu.

\section{3) Interpretasi Ikonologis}

Pada akhirnya membutuhkan yang lebih dari sekedar kedekatan dengan tema atau konsep yang spesifik telah membawa sumber literasi. Prinsip dasar yang mendasari pilihan dan representasi motif (tema) seperti halnya produksi dan interpretasi gambar, cerita dan kiasan dimana memberikan makna terhadap penyusunan formal dan prosedur teknis dalam berkarya. Manusia tidak bisa berharap menemukan sebuah teks individual yang akan menyerang prinsipprinsip dasar. Untuk memegang prinsip tersebut diperlukan kecakapan (faculty) mental yang dapat dibandingkan terhadap diagnosa — sebuah kecakapan yang tidak bisa dideskripsikan lebih baik dari menghilangkan terminologi "intuisi sintesis" dan mungkin lebih baik dibangun pada bakat orang awam daripada sarjana terpelajar.

Subjektivitas dan irasional yang bersumber pada interpretasi (bagi setiap pendekatan intuitif akan bisa dikondisikan melalui psikologi interpretator dan “Weltanschauung”), hal yang lebih penting dari aplikasi keduanya adalah melakukan koreksi dan terbukti sangat diperlukan dimana hanya analisis ikonografis dan deskripsi pra-ikonografis yang bersangkutan. Ketika pengalaman praktis dan pengetahuan terhadap sumber literasi bisa menyesatkan apabila ketidakpandangbuluan digunakan di karya seni, bagaimana banyak bahaya yang bisa dipercayai oleh intuisi murni dan sederhana. Pengalaman praktis dapat dikoreksi melalui wawasan jenis kondisi historis, objek, dan peristiwa yang diekspresikan berupa : 
- Bentuk (sejarah gaya).

- Pengetahuan sumber literasi yang telah mengoreksi dengan wawasan melalui cara macam kondisi historis.

- Tema spesifik dan konsep yang diekspresikan melalui objek dan peristiwa (jenis sejarah).

- Intuisi sintetis menjadi dikoreksi dengan wawasan melalui cara di macam kondisi historis, generalisasi dan tendensi esensial pikiran manusia yang diekspresikan melalui tema spesifik dan konsep.

Tabel 1.

Sinopsis Analisis Ikonografis Sumber: Dokumentasi pribadi, 2017

\begin{tabular}{|c|c|}
\hline Object of Interpretation & Act of Interpretation \\
\hline $\begin{array}{l}\text { Primary or natural subject matter } \\
\text { factual, expressional) } \\
\text { constituting the world of artistic } \\
\text { motifs. }\end{array}$ & $\begin{array}{l}\text { Pre-iconographical } \\
\text { description (andpseudo- } \\
\text { formal analysis). }\end{array}$ \\
\hline $\begin{array}{l}\text { S. Secondary or conventional } \\
\text { subject matter, confituting the } \\
\text { world of images, stories, and } \\
\text { allegories. }\end{array}$ & Iconographical analysis. \\
\hline $\begin{array}{l}\text { I. Intrinsic meaning or content, } \\
\text { constituting the world of } \\
\text { "symbolical values". }\end{array}$ & Iconological interpretation \\
\hline $\begin{array}{l}\text { Makna atau subject matter utama } \\
\text { atau alami: bersifat faktual dan } \\
\text { ekspresional -mengangkat dunia } \\
\text { m otif (tem a-tem a) artistik }\end{array}$ & $\begin{array}{c}\text { Deskripsi pra-ikonografis (analisis } \\
\text { pseudo-form al) }\end{array}$ \\
\hline $\begin{array}{l}\text { Makna atau subject matter } \\
\text { sekunder atau konvensional - } \\
\text { mengangkat dunia gambar, cerita } \\
\text { dankiasan }\end{array}$ & Analisis ikonografis \\
\hline $\begin{array}{l}\text { 1. Makna intrinsik atau konten - } \\
\text { mengangkat dunia nilai } \\
\text { "simbolis" }\end{array}$ & Interpretasi ikonologis \\
\hline
\end{tabular}

\section{Metode Penelitian}

\section{Jenis dan Desain Penelitian}

Penelitian kualitatif adalah penelitian yang mencoba memahami fenomena dalam seting dan konteks naturalnya (bukan di dalam laboratorium), yakni peneliti tidak berusaha memanipulasi fenomena yang diamati (Leedy \& Ormord, dalam Sarosa, 2017:8) Penelitian kualitatif merupakan penelitian naturalistik atau alamiah, etnografi, interaksionis simbolik, perspektif ke dalam, etnometodologi, fenomenologis, studi kasus, interpretatif, ekologis, dan deskripstif. (Moleong, 2004: 10) Penelitian kualitatif berupaya membangun pandangan objek yang diteliti secara rinci melalui penjelasan oleh kata-kata (essay), gambaran holistik, serta rumit. 
Secara rinci penelitian ini dipahami berupa pengamatan, wawancara, atau penelaahan dokumen.

Metode kualitatif ini digunakan karena beberapa pertimbangan. Pertama, menyesuaikan metode kualitatif lebih mudah apabila berhadapan dengan kenyataan jamak. Kedua, metode ini menyajikan secara langsung hakikat hubungan antara peneliti dan responden. Ketiga, metode ini lebih peka dan lebih dapat menyesuaikan diri dengan banyak penajaman pengaruh bersama terhadap pola-pola nilai yang dihadapi. (Moleong, 2004: 4)

\section{a. Cara Pengumpulan Data}

Pemilihan metode penelitian akan menentukan teknik dan alat pengumpulan data yang digunakan. Secara umum, dalam penelitian kualitatif alat pengumpulan data yang paling serign digunakan adalah wawancara (termasuk focus group discussion), pengamatan lapangan (termasuk pengamatan partisipatif), dan telaah dokumen. (Sarosa, 2017:41) Pengumpulan data akan dilakukan dengan kajian pustaka, wawancara dan observasi langsung. Kajian pustaka dilakukan peneliti untuk melacak dan mengkaji literatur-literatur termasuk di dalamnya landasan teoretis seperti buku, jurnal, hasil penelitian, artikel dan liputan media massa yang berkaitan dengan objek penelitian. Hal ini dilakukan untuk menunjang landasan pemikiran dan memperdalam konsep serta penulisan untuk mengembangkan analisis di dalam penelitian.

Wawancara dilakukan secara mendalam, tidak berstruktur ketat, tidak dilakukan secara formal karena dilakukan secara berulang-ulang terhadap partisipan yang ditunjuk. Penulis juga tidak selalu bisa bertemu secara langsung dengan partisipan wawancara karena disesuaikan dengan situasi dan kondisi di lapangan. Wawancara bisa dilakukan melalui e-mail. Observasi akan dilakukan oleh penulis dengan melihat langsung praktik ritual upacara tradisi mitoni di kawasan Kroya, Cilacap, Jawa Tengah.

\section{b. Sampel Penelitian}

Teknik sampling dalam penelitian kualitatif dipilih dari suatu populasi, sehingga dapat digunakan untuk mengadakan generalisasi. Jadi, sampel benar-benar mewakili ciri-ciri suatu populasi. (Moleong, 2004: 223) 


\section{E. Analisis Data}

Data yang akan dianalisis berupa studi kasus upacara mitoni di kawasan Kroya, Cilacap, Jawa Tengah dan didukung oleh observasi, wawancara, dan studi referensi yang dapat menunjang penelitian. Teknik pengolahan data dilakukan dengan menganalisis secara rinci data-data yang terkumpul melalui hasil kajian pustaka, wawancara dan observasi langsung juga tidak langsung terhadap karya serta senimannya. Analisis data dilakukan secara kualitatif yang dilakukan secara terus-menerus untuk menguji beberapa gejala meliputi ruang, waktu, perilaku, artefak kemudian membaginya ke dalam bagian-bagian dalam konteks abstraksi data dan catatan lapangan.

Penelitian kualitatif cenderung menghasilkan jumlah data yang sangat banyak dan kurang terstruktur. Jumlah data tersebut jelas membutuhkan perencanaan dan strategi yang tepat untuk mengolah dan menganalisis. Tiga teknik dalam analisis penelitian jenis ini yaitu hermeneutics, semiotics, dan analisis naratif. (Sarosa,2017:41) penelitian ini menggunakan teknik analisis data semiotics. Untuk memahami tanda dan simbol yang alzim digunakan dalam domain ilmu pengetahuan tertentu dan memahami aturan pemakaiannya. Ide dasar penggunaan semiotics adalah menemukan aturan yang mengatur perilaku manusia. (Myers dalam Sarosa,2017:90)

Reduksi data juga dilakukan guna mempertegas, memperjelas, membuat fokus, mengambil hal-hal yang penting atau patok serta membuang hal-hal yang tidak penting, sehingga data diatur dan memperoleh kesimpulan. Reduksi data merupakan bagian dari analisis yaitu bentuk analisis yang menajamkan, menggolongkan, mengarahkan, membuang yang tidak perlu dan mengorganisasi data hingga kesimpulan-kesimpulan akhir dapat ditarik dan diverifikasi. (Moleong, 2004: 247) Data kualitatif dapat disederhanakan dan transformasikan dalam berbagai macam cara yaitu melalui seleksi yang ketat, ringkasan atau uraian singkat, menggolongkan data di dalam satu pola yang lebih luas dan sebagainya, mengubah data ke dalam angka-angka atau peringkat-peringkat. "Reduksi data dilakukan dengan melakukan abstraksi yaitu usaha membuat rangkuman inti, proses dan pernyataan-pernyataan yang perlu dijaga, sehingga tetap berada di dalamnya". (Moleong, 2004: 247) Penelitian ini nantinya akan mendapatkan banyak data kemudian penulis memilah data mana saja yang koheren untuk menjawab pertanyaan dari rumusan masalah penelitian ini yaitu 
bagaimana visualisasi dan interaksi simbolik pada ritual tradisi mitoni di kawasan Kroya, Cilacap, Jawa Tengah.

\section{PEMBAHASAN}

\section{A. Analisis Visualisasi Simbolik Tradisi Ritual Mitoni}

\section{Simbolisasi Ritual Mitoni secara umum}

Prosesi pertama adalah melakukan sungkeman yang ditujukan kepada kedua orang tua dan mertua, kemudian calon ibu mengganti pakaian untuk acara siraman. Pihak yang melakukan siraman berjumlah 7 orang yang terdiri dari dari ayah, ibu yang juga bertugas mengoleskan semacam sabun yang berwarna-warni di tengah perut, mertua, nenek, nenek bibi, salah satu ibu tetangga, pinisepuh yang menyirami harus ibu-ibu yang sudah mempunyai cucu. Setelah acara sungkeman selesai calon ibu dibawa ke ruang ganti untuk berganti kostum dan di tempat berbeda ibu dan mama mertua calon ibu meracik air suci perwita adi yang berasal dari 7 sumber mata air dan mencampur sekar setaman. Prosesi siraman dilakukan oleh tujuh orang yang terdiri dari ayah, ibu, kedua mertua, nenek, nenek bibi, salah satu ibu tetangga, dan ibu-ibu yang sudah mempunyai cucu. Acara siraman juga memiliki tujuan lainnya yaitu penyucian si ibu dan anak.

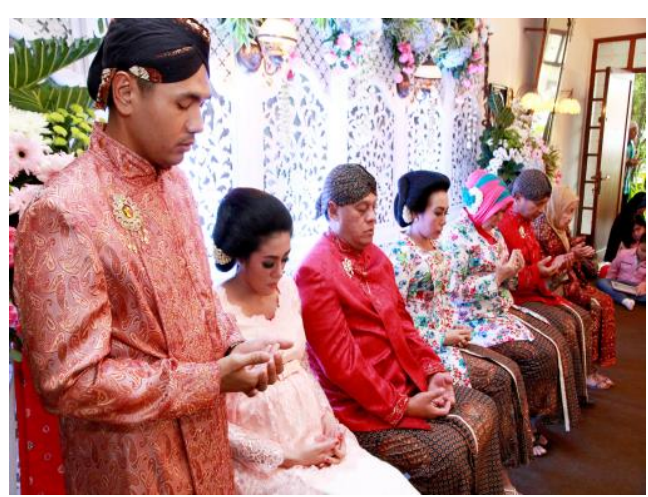

Gambar 1. Doa Bersama yang dilakukan oleh Calon Ayah dan Calon Ibu didampingi oleh Kedua Orang Tua beserta Mertua dilanjutkan dengan Acara Sungkeman. (Sumber:https://ayurianna.com/2015/07/02/pr egnancy-upacara-mitoni/, diakses tanggal 30 September 2017, pukul 18.46 WIB)

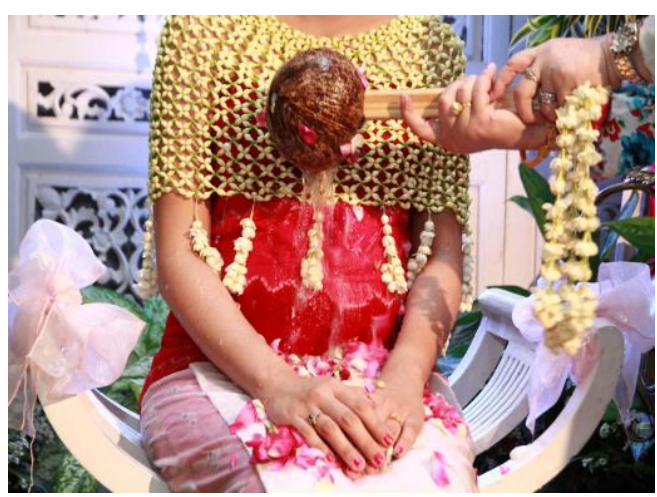

Gambar 2. Bagian Perut merupakan Tempat paling Utama untuk disiram atau dimandikan. (Sumber:https://ayurianna.com/2015/07/02/pre gnancy-upacara-mitoni/, diakses tanggal 30 September 2017, pukul 18.46 WIB)

Prosesi selanjutnya adalah muloni yaitu ayah dan ayah mertua calon ibu menuangkan air dari kendi untuk wudhu, kemudian ibu beserta ibu mertua bersama-sama memecahkan kendi sebagai pembuka jalan agar proses kelahiran 
bayinya lancar. Prosesi ini bisa dianggap sebagai wujud doa restu dan dukungan para orang tua terhadap kehamilan yang sedang dijalani oleh anak serta anak menantu mereka. Selain itu, di dalam tahap ini, para orang tua juga memanjatkan doa kepada Tuhan Yang Maha Esa agar diberikan kemudahan dan kelancaran dalam proses kehamilan serta kelahiran calon jabang bayi.

Setelah mengalami proses siraman dan muloni, calon ibu dipakaikan kain sebanyak 7 warna dan suami bertugas nyelorot teropong alias melepaskan atau meloloskan teropong dari kayu lewat bagian dalam kain warna-warni itu. Kemudian dilanjutkan oleh ibu yang nyelorot telur dan harus dijatuhkan ke tanah sampai pecah, hal ini melambangkan kelahiran bayi yang lancar dan normal.

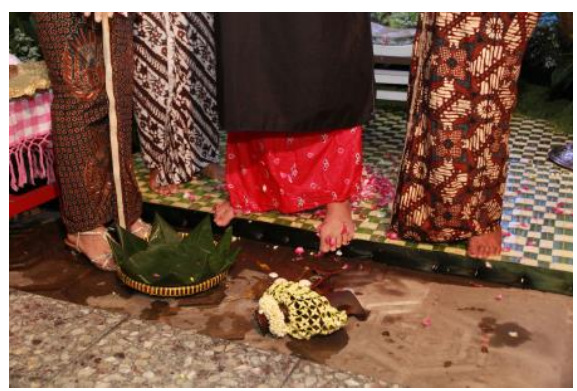

Gambar 3. Prosesi Nyelorot atau Brojolan (Sumber:https://ayurianna.com/2015/07/02/pregnancyupacara-mitoni/, diakses tanggal 30 September 2017, pukul 18.46 WIB)

Prosesi berikutnya yaitu pontas-pantes yang mengharuskan calon ibu berganti kain dan kebaya sebanyak tujuh kali. Pembawa acara akan mengajukan pertanyaan kepada audiensi apakah sudah pantas atau belum hingga menemukan kain atau kebaya mana yang paling pantas dan cocok untuk dikenakan calon ibu. Biasanya percobaan ini menemukan kecocokan pada kain ketujuh yang ditandai dengan kesepakatan audiensi berkata "pantas".

Tigas kendhit adalah prosesi yang dilakukan oleh calon ayah diharuskan memotong janur yang dililitkan ke perut calon ibu dengan keris, mundur tiga langkah, kemudian balik kanan dan langsung lari ke luar rumah. Calon ayah harus berlari kencang hingga ke luar rumah. Prosesi ini merupakan simbol kesigapan calon ayah dalam menjaga dan menyambut kelahiran bayinya kelak.

Brojolan cengkir gading merupakan dua butir kelapa yang sudah diukir gambar wayang Kamajaya-Kamaratih atau Arjuna-Sembadra harus digelindingkan dari balik kain yang dipakai oleh calon ibu sebagai simbol proses kelahiran calon bayi, kemudian diterima oleh ibu dan ibu mertua secara bergantian untuk ditimang, dinyanyikan, dan ditidurkan selayaknya cucu sendiri. 
Angreman alias duduk di atas tumpukan enam pasang kain atau kebaya dari sisa proses pontes-pantes dan hanya kain ketujuh yang akan dipakai, sedangkan jarik yang sebelumnya dipakai sebagai alas duduk atau alat "angrem" atau duduk mengeram. Prosesi ini juga disertai dengan calon ibu yang disuapi oleh calon ayah dengan nasi tumpeng dan bubur merah putih. Hal tersebut menandakan calon ibu akan selalu menjaga calon jabang bayi dan calon ayah yang akan selalu menghidupi keluarganya yang biasa disebut dengan dhahar ajang cowek. Setelah selesai makan, ada juga calon ibu dan ayah melanjutkan ke tahapan mapanaken susuh yaitu membawa baju-baju yang kurang pantas tadi ke tempat tidur, seolaholah mempersiapkan alas tidur yang nyaman untuk calon jabang bayi.

Proses selanjutnya adalah memecah kelapa gading yang telah diberikan oleh si nenek ke ayah. Kelapa gading tersebut biasanya telah digambari dengan figur wayang yang berpasangan pada permukaan dengan harapan kelak jika anak lakilaki memiliki paras tampan dan berkarakter seperti Arjuna atau Kamajaya, sedangkan anak perempuan kelak berwajah cantik, anggun, serta luwes seperti Sembadra atau Kamaratih. Makna lainnya adala apabila pada saat membelah kelapa oleh calon ayah air yang keluar dari dalam buah memancur berarti prediksi jenis kelamin jabang bayi adalah laki-laki, namun apabila air yang keluar hanya mrembes atau mengalir keluar langsung menuju tanah maka dianggap berjenis kelamin perempuan. Hal ini menunjukkan bahwa orang Jawa bermain filosofi melalui simbol-simbol yang dibuat untuk acara tradisi seperti mitoni.

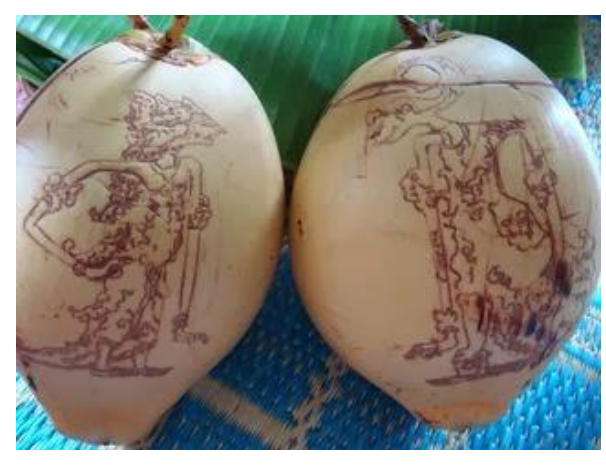

Gambar 4.

Figur Wayang Berpasangan (atas) dan Prosesi Pecah Kelapa (bawah) (Sumber: http://www.hipwee.com/wedding/tentang-acara-mitoni-atau-tujuhbulanan-budaya-jawa-yang-kian-terlupakan/, diakses tanggal 30 September 2017, pukul 18.37 WIB)

Rangkaian upacara mitoni akhirnya ditutup dengan prosesi dodol dhawet dan rujak yang dilakukan oleh calon ibu, sedangkan calon ayah berdiri di samping untuk memayungi dari panas dan hujan. Calon ibu akan membuat rujak yang 
kemudian akan dijual kepada para tamu yang dibeli dengan kereweng atau uanguangan dari bahan tanah liat. Prosesi ini pun merupakan sebuah harapan agar jabang bayi mendapatkan banyak rejeki untuk dirinya dan juga bagi kedua orang tuanya. Rangkaian acara mitoni diakhiri sebelum matahari terbenam dengan harapan jabang bayi pada saat lahir ke dunia diberi keselamatan, rejeki, dan diberi pertolongan dari Tuhan Yang Maha Esa.

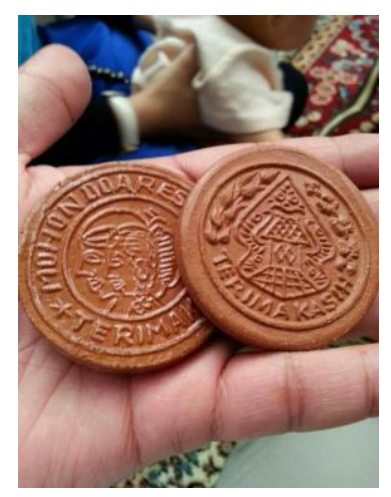

Gambar 5.

Dodol Dhawet dan Kreweng (Sumber: http://www.hipwee.com/wedding/tentang-acara-mitoni-atautujuh-bulanan-budaya-jawa-yang-kian-terlupakan/, diakses tanggal 30 September 2017, pukul 18.37 WIB)

\section{Simbolisasi Mitoni pada Masa Kini}

Perkembangan zaman tidak seutuhnya mengubah kebudayaan atau tradisi suatu masyarakat. Penulis menemukan prosesi ritual mitoni di daerah Kroya, Cilacap, Jawa Tengah namun terdapat beberapa kegiatan yang tidak dimunculkan. Berikut ini adalah hasil pengamatan dan observasi sebagai berikut:

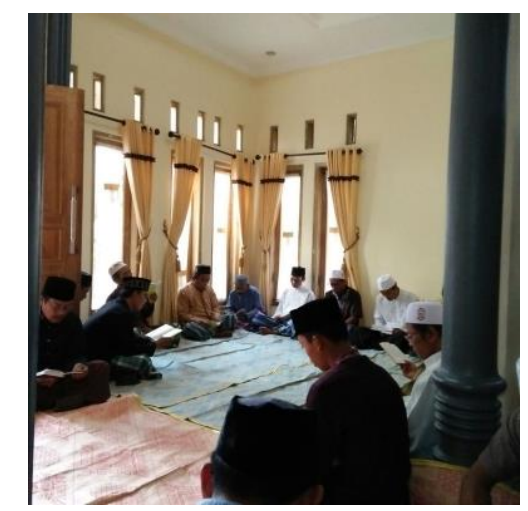

Gambar 6. Pengajian (Foto: Probosiwi, 2017)

Pengajian merupakan acara syukuran yang dilakukan oleh pihak keluarga si jabang bayi sebagai wujud rasa syukur. Di dalam prosesi ini dibacakan QS. Yunus yang dipimpin oleh seorang ustadz dan dilakukan secara berjamaah. 
Pada acara kepungan, tuan rumah menyediakan oleh-oleh untuk diberikan kepada para tamu yang datang untuk mengaji berupa seprangkat makanan (ketupat, lepet) serta masakan (nasi, telur rebus, oseng mie, kerupuk, ayam, dan sebagainya). Orang Jawa seringkali menyebutnya sebagai sego berkat yang ditaruh di dalam wadah keranjang plastik. Setelah semua makanan dan masakan ditata di dalam keranjang plastik, kemudian keranjang tersebut dibungkus dengan tas kresek agar para tamu dapat membawa bingkisan dengan mudah, tidak kotor, dan tidak mudah tumpah. Bungkusan ini merupakan wujud rasa syukur dengan karunia dari Tuhan Yang Meha Esa dikemas dalam sedekah berupa makanan yang diberikan kepada orang lain.

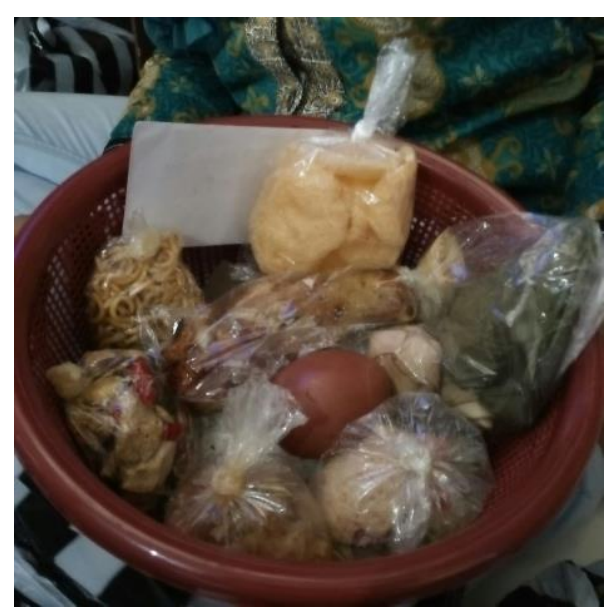

Gambar 7. Sego Berkat

(Foto: Probosiwi, 2017)

Beberapa makanan yang dimasukkan ke dalam keranjang plastik juga disuguhkan pada saat acara kepungan berlangsung yang diracik atau ditata pada tiap piring. Sajian ini didampingi dengan jajanan lainnya seperti roti, buah jeruk, mutiara, dan minuman teh panas. Hal ini ditujukan agar para tamu yang hadir bisa menikmati makanan di lokasi. Tamu yang hadir juga diberi sajian makanan secara prasmanan oleh tuan rumah yang terdiri dari nasi, ayam goreng, oseng tahu, oseng mie, gudangan, kerupuk, dan sebagainya. 


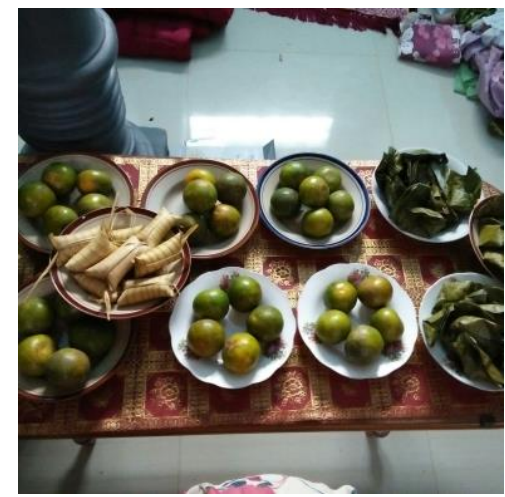

Gambar 8.

Suguhan Piringan untuk Tamu yang Hadir di Lokasi (Foto: Probosiwi, 2017)

Setelah prosesi siraman berakhir, hari menjelang sore calon ibu melakukan kegiatan di luar rumah yaitu berkumpul dengan anak-anak kecil di sekitar tempat tinggalnya. Anak-anak kampung dipanggil dan disuruh melakukan kepungan (makan kecil), bagi mereka yang tidak ikut dalam kerumunan diberi jatah nasi sebanyak satu bungkus. Setelah diberi jatah makan, kemudian mereka saling berebut mengambil uang receh di dalam ember yang berisi belut. Calon ibu ikut mendampingi mereka dan suasana riuh serta ceria mengiringi kegiatan ini, ada beberapa anak yang tidak mendapatkan uang receh tetapi belut. Menu yang disajikan tidak jauh berbeda dengan yang disiapkan di dalam rumah untuk para tamu pengajian. Masakan ini ditata pada sebuah tampah besar yang dialasi daun pisan berisi nasi, gudangan, irisan telur rebus, oseng tahu, oseng mie, dan lain-lain. Anak-anak memakan masakan ini dengan sangat meriah dan berlomba agar bisa menghabiskan. Setelah selesai makan dan berusaha mencari uang receh pada ember berisi belut dan prosesi ini diakhiri dengan pembagian uang saku kepada anak-anak oleh calon ibu sebagai wujud berbagi kebahagiaan serta rasa syukur. Jumlah nominal yang dibagikan tidak banyak, namun mampu membuat mereka merasa senang. 


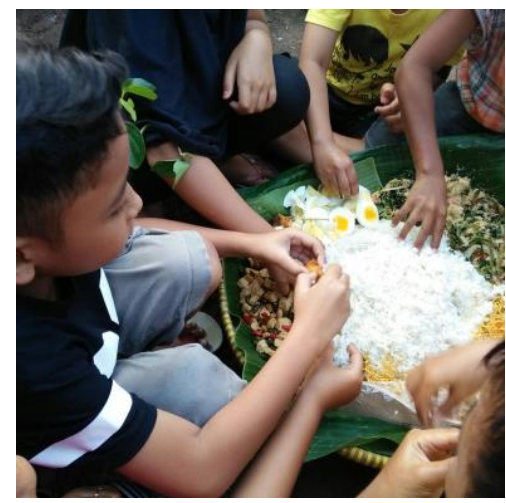

Gambar 9. Kepungan, anak-anak berebut memakan nasi yang disajikan. (Foto: Probosiwi, 2017)

\section{B. Tahap-tahap Kebudayaan pada Ritual Tradisi Mitoni Masa Kini}

Tabel 2.

Analisis Tahap-Tahap Kebudayaan

\begin{tabular}{|c|c|c|}
\hline Tahap Mitis & Tahap Fungsionil & Tahap Ontologis \\
\hline $\begin{array}{l}\text { 1. Prosesi siraman masih } \\
\text { dilakukan dengan } \\
\text { menggunakan berbagai } \\
\text { bunga yang } \\
\text { dicampurkan pada } \\
\text { ember air untuk mandi. }\end{array}$ & $\begin{array}{l}\text { 1. Prosesi sungkeman } \\
\text { pada acara siraman } \\
\text { dihapus dan diganti } \\
\text { dengan pengajian yang } \\
\text { dilakukan oleh bapak- } \\
\text { bapak. }\end{array}$ & $\begin{array}{l}\text { 1. Kostum yang } \\
\text { digunakan calon ibu } \\
\text { tidak lagi memakai } \\
\text { kebaya dan jarik } \\
\text { sejumah tujuh buah. }\end{array}$ \\
\hline $\begin{array}{l}\text { 2. Kelapa gading yang } \\
\text { digambari figur } \\
\text { wayang Kamajaya dan } \\
\text { Kamaratih. }\end{array}$ & $\begin{array}{l}\text { 2. Siraman hanya } \\
\text { dilakukan oleh dukun } \\
\text { (mbah dukun) dan } \\
\text { tidak dilanjutkan } \\
\text { dengan acara brojolan } \\
\text { dan pecah kelapa. }\end{array}$ & $\begin{array}{l}\text { 2. Kemasan makanan dan } \\
\text { masakan untuk } \\
\text { suguhan ditata ke } \\
\text { dalam sebuah } \\
\text { keranjang plastik lalu } \\
\text { dibungkus tas kresek. }\end{array}$ \\
\hline \multirow[t]{3}{*}{$\begin{array}{l}\text { 3. Ritual tradisi mitoni } \\
\text { dilakukan di waktu } \\
\text { pagi hari menjelang } \\
\text { petang. }\end{array}$} & $\begin{array}{l}\text { 3. Setelah siraman, calon } \\
\text { ibu langsung dibawa ke } \\
\text { kamar untuk ganti baju } \\
\text { dan tidak dilanjutkan } \\
\text { dengan muloni serta } \\
\text { acara pontas-pantes. }\end{array}$ & $\begin{array}{l}\text { 3. Para tamu undangan } \\
\text { diminta untuk makan } \\
\text { bersama secara } \\
\text { prasmanan. }\end{array}$ \\
\hline & $\begin{array}{l}\text { 4. Prosesi dodol dhawet } \\
\text { diganti dengan makan } \\
\text { besar (kepungan) dan } \\
\text { mencari receh di dalam } \\
\text { ember berisi belut yang } \\
\text { dilakukan oleh anak- } \\
\text { anak kecil di kampung. }\end{array}$ & $\begin{array}{l}\text { 4. Tuan rumah } \\
\text { melaksanakan } \\
\text { pengajian yang } \\
\text { dilakukan oleh bapak- } \\
\text { bapak. }\end{array}$ \\
\hline & $\begin{array}{l}\text { 5. Calon ibu membagikan } \\
\text { uang saku kepda anak- } \\
\text { anak. }\end{array}$ & \\
\hline
\end{tabular}




\section{Interaksi Simbolik Tradisi Ritual Mitoni}

Tabel 3.

Analisis Ikonografis pada Ritual Tradisi Mitoni

\begin{tabular}{|c|c|}
\hline Act of Interpretation & Object of Interpretation \\
\hline $\begin{array}{l}\text { Deskripsi pra-ikonografis } \\
\text { (analisis pseudo-formal) }\end{array}$ & $\begin{array}{l}\text { 1. Secara faktual dan ekspresional tampak setting tempat ritual } \\
\text { mitoni dibiarkan alami, tidak dibuatkan lokasi khusus, atau } \\
\text { semacam penambahan aksesoris dan dekorasi. } \\
\text { 2. Calon ibu melakukan siraman dengan dibalut jarik dan dibantu } \\
\text { oleh seorang duku wanita. } \\
\text { 3. } \begin{array}{l}\text { Bungkusan makanan (sego berkat) dikemas dalam keranjang } \\
\text { plastik. }\end{array} \\
\text { 4. Sajian makanan untuk tamu undangan diletakkan pada piring } \\
\text { terdiri dari buah jeruk, ketupat, lepet, the panas, dan roti. } \\
\text { 5. Menu makan bersama terdiri dari nasi, gudangan, telur rebus, } \\
\text { oseng tahu, oseng mie, kerupuk. } \\
\text { 6. Pengajian dilakukan di rumah calon ibu yang dihadiri oleh } \\
\text { bapak-bapak. }\end{array}$ \\
\hline Analisis ikonografis & $\begin{array}{l}\text { 1. Kelapa gading, gambaran calon jabang bayi yang kelak berjenis } \\
\text { kelamin atau perempuan dan mewarisi karakter atau sifat dari } \\
\text { tokoh wayang yang dipilih. } \\
\text { 2. Bunga, dicampurkan pada air untuk proses siraman agar calon } \\
\text { ibu bersih dari segala rintangan dan hal-hal jahat yang } \\
\text { menghalangi jalannya kelahiran. } \\
\text { 3. Ketupat dibelah, sebagai simbol jalan kelahiran agar diberi } \\
\text { kemudahan dan kelancaran. }\end{array}$ \\
\hline Interpretasi ikonologis & $\begin{array}{l}\text { 1. Pengajian yang dilakukan oleh bapak-bapak sebagai pengiring } \\
\text { acara siraman yang dilakukan oleh seorang dukun wanita (mbah } \\
\text { dukun). Bunga yang dicampurkan ke dalam air hanya berfungsi } \\
\text { sebagai pengharum saja dan fungsinya digantikan dengan bacaan } \\
\text { QS. Yusuf dan doa-doa yang dilantunkan. } \\
\text { 2. Lokasi siraman dilakukan di dalam kamar mandi dan hanya } \\
\text { dilakukan oleh dukun wanita. } \\
\text { 3. Sego berkat ditata bersama dengan jajanan pasar (ketupat, lepet, } \\
\text { roti) yang menandakan prinsip fleksibilitas dalam penyajian. } \\
\text { 4. Baju yang dikenakan oleh calon ibu menandakan ciri orang yang } \\
\text { berpikiran modern. } \\
\text { Kelapa gading tidak dibelah, hanya diletakkan berdekatan dengan } \\
\text { prosesi siraman, sehingga calon ibu tidak lagi mengharapkan } \\
\text { jenis kelamin calon bayi diketahui melalui buah tersebut. } \\
\text { Calon ibu mengundang anak-anak kampung untuk makan } \\
\text { bersama dan mencari uang receh di dalam ember berisi belut agar } \\
\text { kemeriahan acara menjadi terlihat. } \\
\text { Calon ibu membagikan uang saku dan bukan berjualan es dawet } \\
\text { yang dibeli dengan menggunakan uang kreweng, harapannya } \\
\text { mendapatkan banyak rejeki untuk dirinya dan juga bagi kedua } \\
\text { orang tuanya. Namun, calon ibu mengharap agar nanti calon } \\
\text { anaknya menjadi pribadi yang suka membantu sesama. }\end{array}$ \\
\hline
\end{tabular}

\section{KESIMPULAN}

1. Perkembangan zaman dan pendidikan mempengaruhi pola pikir dari masyarakat Jawa di masa kini. Masyarakat Jawa tidak menghilangkan semua tradisi yang ada, hanya saja disesuaikan dengan kondisi sekitar dan 
masalah finansial. Tradisi yang masih dilestarikan dikemas dalam acara yang lebih singkat dan fleksibel.

2. Simbolisasi ritual tradisi mitoni masa kini dibuat lebih sederhana namun tetap mengangkat kearifan lokal daerah di Kroya, Cilacap, Jawa Tengah yaitu pembuatan lepet untuk kelengkapan pada sego berkat.

3. Aktivitas pengganti ritual yang lain dapat diterapkan sepanjang tidak mengurangi kelancaran acara, dengan catatan rangkaian yang berbeda tersebut mengandung makna yang hampir mirip.

\section{DAFTAR PUSTAKA}

\section{Buku}

Harsojo. 1967. Pengantar Antropologi (Jakarta: Binatjipta).

Hartoko, Dick. 1988. Strategi Kebudayaan (Terj.). Van Peursen. Strategie van de Cultuur. Kanisius: Yogyakarta.

Koentjaraningrat. 1990. Pengantar Ilmu Antropologi. (Jakarta: Rineka Cipta).

Moleong, Lexy J. 2010. Metodologi Penelitian Kualitatif (Edisi Revisi). (Bandung: PT. Remaja Rosdakarya).

Panofsky, Erwin. 1955. Meaning in the Visual Arts (USA: Univeristy of Chicago Press).

Pujileksono, Sugeng. 2016. Pengantar Antropologi: Memahami Realitas Sosial Budaya. (Malang: Intrans Publishing).

Purwadi \& Maziyah, Siti. 2010. Horoskop Jawa (Yogyakarta: Media Abadi).

\section{Jurnal}

Setiawan, Eko. 2015. "Nilai Religius Tradisi Mitoni dalam Perspektif Budaya Bangsa Secara Islami”. Jurnal. Al- 'Adâlah, Volume 18 Nomor 1 Mei halaman. 40

\section{Webtografi}

http://www.sridianti.com/pengertian-mitos.html (diakses tanggal 26 Januari 2017, pukul 14.17 WIB)

https://www.gudeg.net/direktori/710/kehamilan-mitoni.html (diakses tanggal 14 Maret 2017, pukul 10.21 WIB) 